Review Article

\title{
Azilsartan: the novel ARB with unique mechanism of action
}

\author{
Jagdish S. Hiremath ${ }^{1}$, Anoop L. Hajare ${ }^{2 *}$, Sunny R. Chinchansur ${ }^{2}$, Arindam Dey ${ }^{2}$, Rishi Jain ${ }^{2}$
}

${ }^{1}$ Director, Cath Lab, Ruby Hall Clinic, Pune, Maharashtra, India ${ }^{2}$ Medical Services, Emcure Pharmaceuticals Ltd., Pune, Maharashtra, India

Received: 18 January 2017 Accepted: 30 January 2017

*Correspondence to:

Dr. Anoop L. Hajare,

Email: anoophajare@gmail.com

Copyright: (C) the author(s), publisher and licensee Medip Academy. This is an openaccess article distributed under the terms of the Creative Commons Attribution NonCommercial License, which permits unrestricted noncommercial use, distribution, and reproduction in any medium, provided the original work is properly cited.

\begin{abstract}
Hypertension is attributed to be one of the major risk factors in the pathophysiology of ischemic heart disease, stroke, heart failure and renal dysfunction. Angiotensin receptor blockers (ARBs) are one of the first line drugs recommended for clinical use in hypertension by JNC 8. Azilsartan is the recent addition to this family of $\mathrm{ARBs}$ and is perceived as one of the potent antihypertensive drugs today. Azilsartan was developed by replacing the tetrazole ring in candesartan with a 5 member oxo-oxadiazole ring. In India Azisartan was recently approved by DCGI in December 2016 for use in hypertension. In various randomized, double blind clinical studies Azilsartan was found to be to be superior in terms of clinical efficacy over other ARBs like Candesartan, Olmesartan and Valsartan and angiotensin converting enzyme inhibitor like Ramipril. In terms of safety profile Azilsartan appears to be equivalent to the currently available ARBs. Azilsartan due to its superior efficacy and comparative safety profile appear to be a new addition to the armamentarium in the treatment of hypertension.
\end{abstract}

Keywords: ARBs, Azilsartan, Angiotensin, Hypertension, Mas

\section{INTRODUCTION}

Hypertension is considered to be one of the leading risk factors involved in ischemic heart disease, stroke, heart failure and renal dysfunction. ${ }^{1}$ Hypertension management should aim not only to control the blood pressure (BP) but also to reduce the overall cardiovascular $(\mathrm{CV})$ and renal morbidity and mortality. ${ }^{2}$ Angiotensin receptor blockers (ARBs) due to their beneficial effects on $\mathrm{CV}$ and renal morbidity and mortality has emerged as a valuable therapeutic option in the treatment of hypertension.

Losartan was the first ARB to be approved in US in 1995. Since then various ARBs were developed. Azilsartan is the latest addition to this armamentarium. ${ }^{3}$

\section{AZILSARTAN: THE $8^{\text {th }}$ ARB}

Azilsartan medoxomil is a new addition to the ARB class of antihypertensive agents. Azilsartan is approved in USA, Europe and Japan in the treatment of hypertension. It is recently been approved by DCGI (09/12/2016) for use in hypertension. ${ }^{4}$

\section{PHARMACOLOGY OF AZILSARTAN}

Azilsartan was developed by replacing the tetrazole ring in candesartan with the 5 member oxo-oxadiazole ring. This modification has made Azilsartan less acidic and more lipophilic than candesartan. It has also rendered the molecule an unusual capacity to persistently block AT1 receptors for longer periods of time than most ARBs. Thus Azilsartan has an $\mathrm{IC}_{50}$ of $2.6 \mathrm{nM}$ which is much lower than other potent ARBs Olmesartan (6.7 nM) and 
Telmisartan $(5.1 \mathrm{nM})$. This is the reason for higher potency of Azilsartan when compared to other agents. ${ }^{5}$

\section{PHARMACODYNAMICS (PD)}

Azilsartan medoxomil is a prodrug which upon rapid hydrolysis produces Azilsartan which is the active entity. Azilsartan acts by blocking the angiotensin II mediated activation of AT1 receptors. Azilsartan has also been hypothesized to act by stimulating the Mas receptors and thereby offering pleiotropic benefits. Studies suggest that
Azilsartan reduces vascular inflammation, cellular proliferation, fibrosis etc. through Ang (1-7) mediated Mas receptor activity. Azilsartan is also found to modify atherosclerotic lesions, insulin sensitivity and glucose metabolism. In a recent study by Carroll et al it was observed that the treatment with Azilsartan completely antagonized the elevation of BP induced by Angiotensin II, prevented cardiac hypertrophy and reduced renal damage. ${ }^{6}$

Figure 1 represents the mas pathway.

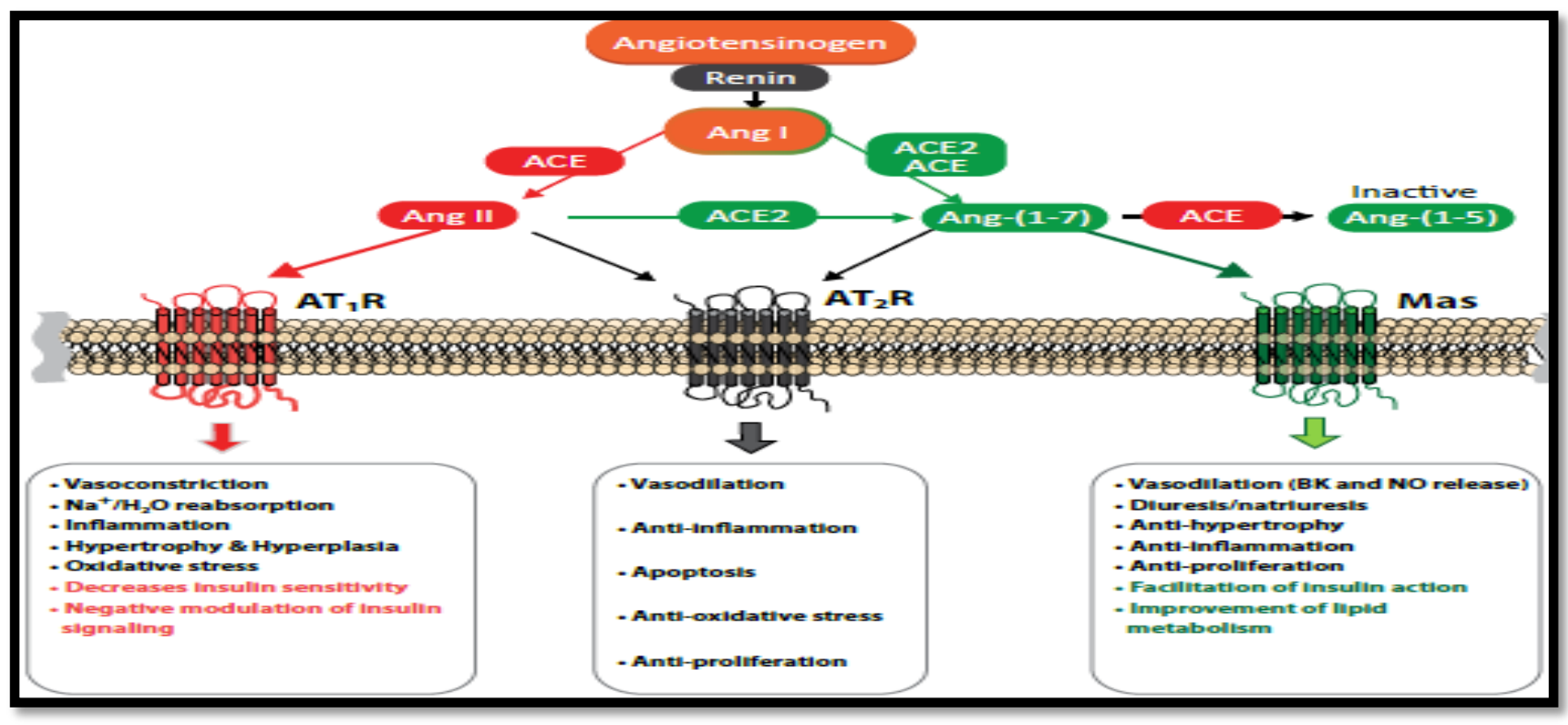

Figure 1: The Mas receptor pathway and the pleiotropic benefits.

The Renin Angiotensin Aldosterone System (RAAS) is the major pathway involved in the action of ARBs. In addition to the ACE/Ang II/AT1 receptor axis (classical), the RAAS possesses a counter-regulatory axis composed of ACE2, angiotensin-(1-7) [Ang-(1-7)] and the Mas receptor. ${ }^{7}$ Recent investigations suggest new aspects in RAAS pathways with detailed exploration and consideration of ACE2/Ang-(1-7)/Mas pathway as an alternative protective pathway. Briefly each component of this alternate pathway is described below.

\section{The ACE2 enzyme}

ACE2 is a membrane-associated zinc metalloprotease and a homologue of the human ACE isoforms, which is highly expressed in several tissues such as human heart, kidney, lungs, and testes. ${ }^{8}$ ACE2 is a catabolic enzyme and is essentially involved in the conversion of both Ang I and Ang II into smaller fragments. It has also been reported that ACE2 more efficiently hydrolyses Ang II than Ang I. ACE2 cleaves the C-terminal amino acid from Ang II and other peptides. The Ang-(1-7) peptide is mainly produced by ACE2 via action on Ang-II. ACE2 can also form Ang-(1-7) less efficiently by conversion of Ang I to Ang-(1-9) with subsequent Ang-(1-7) formation.

\section{The mas receptor}

Mas receptor was identified as a very hydrophobic protein, containing seven potential transmembrane domains were first cloned by Young and co-workers in 1986. Santos et al. established that Ang-(1-7) has limited interaction with AT1 or AT2 receptors and majorly it binds with Mas receptor. ${ }^{9}$

\section{PHARMACOKINETICS (PK)}

Table 1: Pharmacokinetic profile of Azilsartan.

\begin{tabular}{|ll|}
\hline PK Parameter & Finding \\
\hline Bioavailability & $60 \%$ \\
\hline Effect of Food & No \\
\hline $\mathrm{T}_{\max }$ & $1.5-3.0$ hours \\
\hline $\begin{array}{l}\text { Steady state plasma } \\
\text { concentration }\end{array}$ & $5 \mathrm{~d}$ \\
\hline $\mathrm{t}_{1 / 2}$ & 11 hours \\
\hline Elimination & Feces $55 \%$, Urine $45 \%$ \\
\hline
\end{tabular}

Azilsartan is metabolized in the liver via cytochrome P450 (CYP) 2C9 producing two metabolites M-I and MII which are inactive in nature. M-II is the major 
metabolite formed whereas M-I is the minor metabolite. $\underset{1.10,11}{\text { Key pharmacokinetic parameters are shown in Table }}$

\section{DRUG INTERACTIONS}

As per the prescribing information of Azilsartan no clinically significant drug interactions have been observed in studies of Azilsartan medoxomil or Azilsartan given with amlodipine, antacids, chlorthalidone, digoxin, fluconazole, glyburide, ketoconazole, metformin, pioglitazone, and warfarin. Therefore, Azilsartan may be used concomitantly with this medications. ${ }^{10}$

\section{EXPERIMENTAL EVIDENCES}

Data from various preclinical studies evaluated the pleiotropic benefits of Azilsartan in treating various pathological conditions underlying hypertension. A possible role of Azilsartan in metabolic syndrome has been suggested in a study in obese rats demonstrating its insulin sensitizing effect. ${ }^{12,13}$ Beneficial effects like vasculoprotection, left ventricular remodelling has also been demonstrated in various animal studies. ${ }^{14-16}$ Azilsartan is also claimed to have renoprotective effects in terms of reducing proteinuria, albuminuria and glomerular injury. ${ }^{17}$

\section{CLINICAL EVIDENCES}

Various double-blind randomized clinical trials were conducted to evaluate the efficacy and safety of Azilsartan in comparison to other ARBs. In all the clinical trials Azilsartan showed to be more efficacious than the comparator in terms of clinical efficacy. Safety profile was also found to be comparable with the existing ARBs. Below is an outline of the clinical trials conducted with Azilsartan as monotherapy and combination therapy (Table 2 and 3).

Table 2: Azilsartan Medoxomil (AZL-M) as monotherapy.

\begin{tabular}{|c|c|c|c|c|c|c|}
\hline $\begin{array}{l}\text { Study } \\
\text { (year) }\end{array}$ & $\begin{array}{l}\text { Study } \\
\text { type }\end{array}$ & Patients & Duration & Study arms & $\begin{array}{l}\text { Primary end } \\
\text { point }\end{array}$ & Result \\
\hline $\begin{array}{l}\text { Bakris et } \\
\text { al., } 2011^{18}\end{array}$ & $\begin{array}{l}\text { Double- } \\
\text { blind } \\
\text { RCT }\end{array}$ & 1275 & 6 weeks & $\begin{array}{l}\text { AZL-M } \\
20,40,80 \mathrm{mg} \text { or } \\
\text { OLM } 40 \mathrm{mg} \text { or } \\
\text { Placebo }\end{array}$ & $\begin{array}{l}\text { Change from } \\
\text { baseline in } 24 \mathrm{hr} \\
\text { mean SBP and } \\
\text { clinic BP }\end{array}$ & $\begin{array}{l}\text { AZL-M } 80 \mathrm{mg} \text { reduced the } \\
24 \text { hours SBP by } 14.6 \\
\text { mmHg and clinic SBP by } \\
17.6 \mathrm{mmHg} \text { after } 6 \text { weeks. } \\
(\mathrm{P}=0.038)\end{array}$ \\
\hline $\begin{array}{l}\text { White et } \\
\text { al., } 2011^{19}\end{array}$ & $\begin{array}{l}\text { Double- } \\
\text { blind } \\
\text { RCT }\end{array}$ & 1291 & 6 weeks & $\begin{array}{l}\text { AZL-M } 40,80 \\
\text { mg or VAL } 320 \\
\text { mg or OLM } 40 \\
\text { mg or Placebo }\end{array}$ & $\begin{array}{l}\text { Change from } \\
\text { baseline in } 24 \mathrm{hr} \\
\text { mean SBP }\end{array}$ & $\begin{array}{l}\text { AZL-M } 80 \mathrm{mg}(-14.6 \\
\mathrm{mmHg}) \text { vs. OLM } 40 \mathrm{mg}(- \\
12.0 \mathrm{mmHg})(\mathrm{p}=0.009) \text { and } \\
\text { VAL }(-10.2 \mathrm{mmHg}) \\
(\mathrm{p}<0.001)\end{array}$ \\
\hline $\begin{array}{l}\text { Sica et al., } \\
2011^{20}\end{array}$ & $\begin{array}{l}\text { Double- } \\
\text { blind } \\
\text { RCT }\end{array}$ & 984 & 24 weeks & $\begin{array}{l}\text { AZL-M 40, } 80 \\
\text { mg or VAL } 320 \\
\text { mg }\end{array}$ & $\begin{array}{l}\text { Change from } \\
\text { baseline in } 24 \mathrm{hr} \\
\text { mean SBP }\end{array}$ & $\begin{array}{l}\text { AZL-M } 40 \mathrm{mg}(-14.9 \\
\mathrm{mmHg}) \text { and } 80 \mathrm{mg}(-15.3 \\
\mathrm{mmHg}) \mathrm{vs} . \mathrm{VAL} 320 \mathrm{mg}(- \\
11.3 \mathrm{mmHg})(\mathrm{p}<0.001 \text { for } \\
\text { both) }\end{array}$ \\
\hline $\begin{array}{l}\text { Bonner et } \\
\text { al., } 2012^{21}\end{array}$ & $\begin{array}{l}\text { Double- } \\
\text { blind } \\
\text { RCT }\end{array}$ & 884 & 24 weeks & $\begin{array}{l}\text { AZL-M 20-80 } \\
\text { mg or RAM } 2.5- \\
10 \mathrm{mg}\end{array}$ & $\begin{array}{l}\text { Change from } \\
\text { baseline in sitting } \\
\text { trough SBP }\end{array}$ & $\begin{array}{l}\text { AZL-M } 40 \text { mg }(-20.6 \\
\text { mmHg) \& AZL-M } 80 \text { mg(- } \\
21.2 \mathrm{mmHg}) \text { vs. RAM }(-12.2 \\
\mathrm{mmHg})(\mathrm{p}<0.001)\end{array}$ \\
\hline
\end{tabular}

Table 3: Azilsartan Medoxomil (AZL-M) as combination.

\begin{tabular}{|c|c|c|c|c|c|c|}
\hline $\begin{array}{l}\text { Study } \\
\text { (year) }\end{array}$ & $\begin{array}{l}\text { Study } \\
\text { type }\end{array}$ & Patients & Duration & Study arms & $\begin{array}{l}\text { Primary } \\
\text { end point }\end{array}$ & Result \\
\hline $\begin{array}{l}\text { Sica et al., } \\
2012^{22}\end{array}$ & $\begin{array}{l}\text { Double- } \\
\text { blind RCT }\end{array}$ & 1714 & 8 weeks & $\begin{array}{l}\text { AZL-M 20, } \\
40,80 \mathrm{mg} \\
\text { and/or CLD } \\
12.5,25 \mathrm{mg}\end{array}$ & $\begin{array}{l}\text { Change from } \\
\text { baseline in } \\
\text { trough SBP } \\
\text { by ABPM }\end{array}$ & $\begin{array}{l}\text { Clinic SBP: AZL-M/CLD } 40 / 25 \\
\text { and } 80 / 25 \mathrm{mg}(-39.8 \pm 0.88 \mathrm{mmHg}) \\
\text { vs AZL-M } 80 \mathrm{mg}(- \\
24.2 \pm 1.23 \mathrm{mmHg}) \text { and CLD } 25 \\
\mathrm{mg}(-27.1 \pm 1.25 \mathrm{mmHg})\end{array}$ \\
\hline $\begin{array}{l}\text { Weber et } \\
\text { al. } 2014^{23}\end{array}$ & $\begin{array}{l}\text { Double- } \\
\text { blind RCT }\end{array}$ & 566 & 6 weeks & $\begin{array}{l}\text { AZL-M/AML } \\
40 / 5,80 / 5 \mathrm{mg} \\
\text { or AML } 5 \mathrm{mg} \\
\text { + Placebo }\end{array}$ & $\begin{array}{l}\text { Change from } \\
\text { baseline in } \\
24 \text { hr SBP } \\
\text { by ABPM }\end{array}$ & $\begin{array}{l}\text { AZL-M/AML } 40 / 5 \mathrm{mg}(\mathrm{SBP} \\
\text { reduction by }-24.8 \mathrm{mmHg} \text { by } 24 \\
\text { hr ABPM vs. }-13.6 \mathrm{mmHg} \\
\text { reduction in } 24 \mathrm{hr} \mathrm{SBP} \text { by } \\
\text { Placebo + AML } 5 \mathrm{mg}\end{array}$ \\
\hline
\end{tabular}




\section{Dosage}

The recommended dose in India is $80 \mathrm{mg}$ taken once daily. A starting dose of $40 \mathrm{mg}$ for patients who are treated with high doses of diuretics to be considered. It may be administered with or without food. No dose adjustment is required in mild, moderate and severe renal failure and mild to moderate liver failure. However in other regions like Europe and UK the recommended dose is $40 \mathrm{mg}$ once daily which may be increased to $80 \mathrm{mg}$ once daily in patients whose blood pressure is not adequately controlled

\section{ADVERSE DRUG REACTIONS}

In a clinical study conducted by Bakris $\mathrm{G}$ et al, with 1275 patients over 6 weeks the common adverse effects reported were headache $(3.2 \%-5.6 \%)$, dyslipidemia $(3.5 \%-5.6 \%)$ and dizziness $(2.1 \%-2.8 \%) .{ }^{18}$ In another clinical study by White $\mathrm{W}$ et al, with 1291 patients over 6 weeks the adverse effects reported were headache $(4.2 \%$ $6.4 \%)$, dizziness $(1.8 \%-3.6 \%)$, urinary tract infection $(1.1 \%-3.2 \%){ }^{19}$ In the study conducted by Bonner $\mathrm{G}$ et al. ${ }^{21}$ with 884 patients over 24 weeks, nasopharyngitis $(4.4 \%-6.5 \%)$, cough $(1.0 \%-1.4 \%)$ and headache $(3.4 \%-$ $4.1 \%$ ) were the commonly reported adverse effects. Since these reactions are reported voluntarily from a population of uncertain size it is difficult to estimate their frequency or to establish a causal relationship to drug exposure.

\section{DISCUSSION}

The current review aims to focus on the efficacy and safety parameters of the new ARB Azilsartan in the treatment of hypertension.

\section{(a) Azilsartan as monotherapy (Table 2)}

In the clinical study by Bakris $\mathrm{G}$ et al, over 6 weeks there was an additional $2 \mathrm{mmHg}$ reduction with Azilsartan $80 \mathrm{mg}$ in the 24 hour mean SBP in comparison to Olmesartan $40 \mathrm{mg}(\mathrm{P}=0.038)$ and $2.7 \mathrm{mmHg}$ reduction in the clinic SBP $(\mathrm{P}=0.043) .{ }^{18}$ There was also an additional $1.5 \mathrm{mmHg}$ reduction in clinic DBP with Azilsartan 80mg over the Olmesartan 40mg ( $\mathrm{P}=0.044)$. In another clinical study White WB et al, over 6 weeks Azilsartan $80 \mathrm{mg}$ additionally reduced the clinic SBP by $3.5 \mathrm{mmHg}$ and 5.4 $\mathrm{mmHg}$ in comparison to Olmesartan 40mg $(\mathrm{P}=0.008)$ and Valsartan $320 \mathrm{mg}(\mathrm{P}<0.001)$ respectively. ${ }^{19}$ The results were found to be similar for 24 hours mean SBP reductions from the baseline. Azilsartan 40mg dose was found to be noninferior to the Olmesartan $40 \mathrm{mg}$ dose. The responder rate which was defined as the proportion of the population achieving a reduction in clinic SBP $<140 \mathrm{mmHg}$ and/or a reduction of $\geq 20 \mathrm{mmHg}$ was larger for the Azilsartan 80mg group (58\%) in comparison to Olmesartan 40mg (49\%) and Valsartan (49\%) 320mg groups. Statistically significant reductions in SBP/DBP were also found with Azilsartan in comparison to Valsartan in the study by Sica D et al. ${ }^{20}$ Azilsartan was compared in a clinical study by Bonner $G$ et al, with Ramipril for 24 weeks. $^{21}$ Fall in clinic SBP and DBP were significantly lower for Azilsartan 40mg and $80 \mathrm{mg}$ doses in comparison to Ramipril 10mg $(\mathrm{P}<0.001)$. In terms of safety profile cough was reported in $1.4 \%$ subjects in Azilsartan $80 \mathrm{mg}$ groups versus $8.2 \%$ in the Ramipril $10 \mathrm{mg}$ group. However dizziness and hypotension reported with Azilsartan was higher than Ramipril which might be related to greater BP reduction achieved with Azilsartan.

\section{(b) Azilsartan in combination therapy (Table 3)}

In the study by Sica $\mathrm{D}$ et al Azilsartan with Chlorthalidone $(40 / 80 \mathrm{mg}+25 \mathrm{mg})$ produced significantly higher clinic SBP reduction $(-39.8 \pm 0.88 \mathrm{mmHg})$ in comparison to monotherapies with Azilsartan $80 \mathrm{mg}$ $(-24.2 \pm 1.23 \mathrm{mmHg})$ and Chlorthalidone $(-27.1 \pm 1.25 \mathrm{mmHg}){ }^{22}$ Similarly in the study by Weber MA et al, Azilsartan with Amlodipine $(40 \mathrm{mg}+5 \mathrm{mg})$ caused significant reductions in 24 hours mean SBP by $24.8 \mathrm{mmHg}$ versus $-13.6 \mathrm{mmHg}$ as seen with Placebo+Amlodipine 5mg. ${ }^{23}$

With the clinical data available till date Azilsartan appears to be a potent and well tolerated molecule in effectively lowering the BP. The high potency of this molecule can be attributed to its unique oxo-oxadiazole ring. Azilsartan is the only ARB which is approved in combination with chlorthalidone by US-FDA. In India, Azilsartan as a combination therapy is yet to be approved by DCGI.

\section{CONCLUSION}

Azilsartan medoxomil is the $8^{\text {th }}$ ARB to be approved for the treatment of hypertension. With the clinical evidences available Azilsartan appears to be more effective than the other ARBs like Olmesartan, Valsartan and ACE inhibitor Ramipril. Azilsartan is the only ARB to be approved in combination with chlorthalidone by USFDA. Currently monotherapy of Azilsartan in the treatment of hypertension is approved by DCGI in December 2016.

\section{Funding: No funding sources \\ Conflict of interest: None declared \\ Ethical approval: Not required}

\section{REFERENCES}

1. Centers for Disease Control and Prevention. High Blood Pressure Facts. Atlanta, GA: Centers for Disease Control and Prevention; 2011. Available from: http://www.cdc.gov/bloodpressure/facts.htm. Accessed Jan 11, 2017.

2. Antonakoudis G, Poulimenos I, Kifnidis K, Zouras C, Antonakoudis H. Blood pressure control and cardiovascular risk reduction. Hippokratia. 2007;11(3):114-9. 
3. Ripley E, Hirsch A. Fifteen years of losartan: what have we learned about losartan that can benefit chronic kidney disease patients? Int J Nephrol Renovasc Dis. 2010;3:93-8.

4. DCGI Approval for Azilsartan. http://www.cdsco.nic.in/forms/list.aspx?lid=2034\&Id $=11$. Accessed on 05/01/2017).

5. Kurtz TW. Kajiya T. Differential pharmacology and benefit/risk of azilsartan compared to other sartans. Vasc Health Risk Manag. 2012;8:133-43.

6. Carroll MA. Kang Y. Chander PN. Stier CT. Azilsartan is associated with increased circulating Angiotensin-(1-7) levels and reduced renovascular 20-HETE levels. Am J Hypertens. 2015;28(5):66471.

7. Simoes e Silva AC, Silveira KD, Ferreira AJ, Teixeira MM. ACE2, angiotensin-(1-7) and Mas receptor axis in inflammation and fibrosis. British journal of pharmacology. 2013;169(3):477-92.

8. deGodoy MAF, Pernomian L, de Oliviera AM, Rattan S. Biosynthetic Pathways and the Role of the MasReceptor in the Effects of Angiotensin-(1-7) in Smooth Muscles. International Journal of Hypertension. 2012;121740.

9. Young D, Waitches G, Birchmeier C. Isolation and characterization of a new cellular oncogene encoding a protein with multiple potential transmembrane domains. Cell. 1986;45(5):711-9.

10. Product Information: Edarbi oral tablets, azilsartan medoxomil oral tablets. Takeda Pharmaceuticals America, Inc., https://www.edarbi.com/media/pdf/EDARBI-PI.pdf. Accessed on 11/01/17.

11. Kajiya T, Ho C, Wang J. Molecular and cellular effects of azilsartan: A new generation angiotensin II receptor blocker. J Hypertens. 2011;29:2476-83.

12. Zhao M, Li Y, Wang J. Azilsartan treatment improves insulin sensitivity in obese spontaneously hypertensive Koletsky rats. Diabetes Obes Metab. 2011;13:1123-9.

13. Hye Khan MA, Neckar J, Haines J, Imig JD. Azilsartan improves glycemic status and reduces kidney damage in zucker diabetic fatty rats. Am J Hypertens. 2014;27(8):1087-95.

14. Abdelsaid M, Coucha M, Ergul A. Cerebrovasculo protective Effects of azilsartan medoxomil in diabetes. Transl Res. 2014;164(5):424-32.
15. Tarikuz Zaman AK, McLean DL, Sobel BE. The efficacy and tolerability of azilsartan in obese insulinresistant mice with left ventricular pressure overload. J Cardiovasc Pharmacol. 2013;62(4):381-7.

16. Nakamura Y, Suzuki S, Saitoh S, Takeishi Y. New angiotensin II type 1 receptor blocker, azilsartan, attenuates cardiac remodeling after myocardial infarction. Biol Pharm Bull. 2013;36(8):1326-31.

17. Khan AH, Neckar J, Cummens B, Wahl GM, Imig JD. Azilsartan decreases renal and cardiovascular injury in the spontaneously hypertensive obese rat. Cardiovasc Drugs Ther. 2014;28:313-22.

18. Bakris GL, Sica D, White WB, Cushman WC, Weber MA, Handley A et al. Antihypertensive efficacy of hydrochlorothiazide vs chlorthalidone combined with azilsartan medoxomil. Am J Med. 2012;125(12):1229.e1-e10.

19. White WB, Cuadra RH, Lloyd E, Bakris GL, Kupfer S. Effects of azilsartan medoxomil compared with olmesartan and valsartan on ambulatory and clinic blood pressure in patients with type 2 diabetes and prediabetes. J Hypertens. 2016;34(4):788-97.

20. Sica D, White WB, Weber MA, Bakris GL, Perez A, $\mathrm{Cao} \mathrm{C}$ et al. Comparison of the novel angiotensin II receptor blocker azilsartan medoxomil vs valsartan by ambulatory blood pressure monitoring. J Clin Hypertens (Greenwich). 2011;13(7):467-72.

21. Bönner G, Bakris GL, Sica D, Weber MA, White WB, Perez A et al. Antihypertensive efficacy of the angiotensin receptor blocker azilsartan medoxomil compared with the angiotensin-converting enzyme inhibitor ramipril. J Hum Hypertens. 2013;27(8):47986.

22. Sica D, Bakris GL, White WB, Weber MA, Cushman WC, Huang P et al. Blood pressure-lowering efficacy of the fixed-dose combination of azilsartan medoxomil and chlorthalidone: a factorial study. J Clin Hypertens (Greenwich). 2012;14(5):284-92.

23. Weber MA, White WB, Sica D, Bakris GL, Cao C, Roberts A et al. Effects of combining azilsartan medoxomil with amlodipine in patients with stage 2 hypertension. Blood Press Monit. 2014;19(2):90-7.

Cite this article as: Hiremath JS, Hajare AL, Chinchansur SR, Dey A, Jain R. Azilsartan: the novel ARB with unique mechanism of action. Int $\mathrm{J}$ Basic Clin Pharmacol 2017;6:482-6. 